\title{
Evaluation of source data verification in a multicentre cancer trial (PROTECT)
}

\author{
J Athene Lane ${ }^{1 *}$, Michael Davis ${ }^{1}$, Elizabeth Down ${ }^{1}$, Rhiannon Macefield ${ }^{1}$, David Neal ${ }^{2}$, Freddie Hamdy ${ }^{3}$, \\ Jenny Donovan ${ }^{1}$, Hilary Taylor ${ }^{1}$ \\ From 2nd Clinical Trials Methodology Conference: Methodology Matters \\ Edinburgh, UK. 18-19 November 2013
}

\section{Background and aims}

Source Data Verification (SDV) aims to assure data quality and participant safety by checking trial data against source data in site monitoring visits. SDV is resource-intensive but its value is unclear. We evaluated SDV in an ongoing phase III RCT of three prostate cancer treatments (ProtecT) with no planned SDV.

\section{Methods}

Two experienced ProtecT Data Managers reviewed 20 randomly selected participants notes at 9 hospital visits across the UK (around 7\% participants per site). SDV case report forms (CRFs) were completed using hospital and trial records (blinded to original CRFs) including baseline, eligibility, treatment and annual outcome CRFs. CRFs were entered on a separate database. Staff time, accommodation and travel costs were recorded and analysed using university costing software.

\section{Results}

639 SDV CRFs were completed (mean 4/participant) from 161 sets of available records $(90 \%$ of those requested) taking a mean of 51 minutes/participant. Problems encountered included the knowledge required to interpret medical records and interrogate computer systems. SDV and original data were compared for concordance, with errors categorised as critical/major/ minor. Trial CRFs were subsequently modified to increase standardisation of data collection across sites. Staff time was the major resource $(£ 7,041)$ as was $£ 3,126$ of subsistence/travel costs (total $£ 10,167, £ 63$ / participant, with overhead costs $£ 17,480)$.

University of Bristol, Bristol, UK

Full list of author information is available at the end of the article

\section{Conclusions}

SDV was conducted at 9 site visits on around $5 \%$ of participants in a cancer trial. Logistical issues hindered data collection. Comparison of SDV data against trial data helped improved trial CRFs. Further analysis will evaluate data quality gains against the considerable costs.

\section{Authors' details \\ ${ }^{1}$ University of Bristol, Bristol, UK. ${ }^{2}$ University of Cambridge, Cambridge, UK. \\ ${ }^{3}$ University of Oxford, Oxford, UK.}

Published: 29 November 2013

doi:10.1186/1745-6215-14-S1-080

Cite this article as: Lane et al: Evaluation of source data verification in a multicentre cancer trial (PROTECT). Trials 2013 14(Suppl 1):O80.
Submit your next manuscript to BioMed Central and take full advantage of:

- Convenient online submission

- Thorough peer review

- No space constraints or color figure charges

- Immediate publication on acceptance

- Inclusion in PubMed, CAS, Scopus and Google Scholar

- Research which is freely available for redistribution

Submit your manuscript at www.biomedcentral.com/submit
() Biomed Central

\section{() Biomed Central}

(c) 2013 Lane et al; licensee BioMed Central Ltd. This is an Open Access article distributed under the terms of the Creative Commons Attribution License (http://creativecommons.org/licenses/by/2.0), which permits unrestricted use, distribution, and reproduction in any medium, provided the original work is properly cited. 